\title{
Dyslipidemia in subclinical hypothyroidism requires assessment of small dense low density lipoprotein cholesterol (sdLDL-C)
}

\author{
MAIDA SEFEROVIC SARIC ${ }^{1}$, MILJENKA-JELENA JURASIC ${ }^{2}$, SLAVICA SOVIC ${ }^{3}$, \\ BOJANA KRANJCEC ${ }^{1}$, TATJANA GLIVETIC ${ }^{1}$, VIDA DEMARIN ${ }^{4}$ \\ ${ }^{1}$ General Hospital Zabok and Hospital of Croatian Veterans, Zabok, Croatia \\ ${ }^{2}$ University Department of Neurology, Sestre milosrdnice University Hospital Center, Zagreb, Croatia \\ ${ }^{3}$ University of Zagreb, School of Medicine, Stampar School of Public Health and \\ Croatian National Institute of Public Health, Zagreb, Croatia \\ ${ }^{4}$ Croatian Academy of Sciences and Arts, Zagreb, Croatia
}

\begin{abstract}
Background. Usually both hypothyroidism and hyperthyroidism are related to the cardiovascular and cerebrovascular disease development. The relationship between subclinical hypothyroidism has been widely investigated but the findings remain controversial. The aim of the present study was to evaluate the lipid profile in patients with subclinical hypothyroidism (SHypo) in comparison to controls and to determine the association of SHypo and dyslipidemia in attempt to find importance of small dense low-density lipoprotein cholesterol (sdLDL-C) in atherosclerosis.

Material and methods. In this study we included 100 women, aged 30 to 70 years that were divided into subgroups according to their age. According to the values of levels of thyroid hormones they were divided into euthyroid (control) group $(n=64)$ and (newly discovered) subclinical hypothyroidism (SHypo) group $(\mathrm{n}=36)$. A high-sensitivity C-reactive protein (hs-CRP) and lipid profile, including small dense low-density lipoprotein cholesterol (sdLDL-C) were determined. Body weight and height were measured and BMI calculated. History of the current illness, medication, alcohol consumption and cigarettes smoking were noted.

Results. Changed lipid profile as well as elevated triglycerides and sdLDL-C were observed in the group with subclinical hypothyroidism compared to the control group.

Conclusions. It is important to determine serum lipid levels, especially serum sdLDL-C levels at an early stage of subclinical hypothyroidism, since they represent atherogenic LDL particles and are better indicators for dyslipidaemia in subclinical hypothyroidism and the development of atherosclerosis with potential complications such as cardiovascular and cerebrovascular diseases.
\end{abstract}

Key words: dyslipidemia, subclinical hypothyroidism, small dense low density lipoprotein cholesterol, cardiovascular risk, cerebrovascular risk.

\section{INTRODUCTION}

Subclinical hypothyroidism (SHypo) is type of thyroid failure which is characterized by mildly elevated thyroid stimulating hormone (TSH) and normal serum levels of peripheral thyroid hormones. SHypo occurs in $3 \%$ to $8 \%$ of the general population, it is more common in women than in men, and its prevalence increases with age. Patients with SHypo are asymptomatic or have only mild, non-specific symptoms of hypothyroidism, such as constipation and nausea $[1,2]$.

Although thyroid hormones have an impact on lipid metabolism, connection between subclinical hypothyroidism, dyslipidemia and increased risk for atherosclerosis is still a matter of debate [3, 4]. It is known that LDL-C plays an important role in the development of atherosclerosis, but there is more evidence which highlights the importance of its qualitative composition. There are two distinct LDL subclass phenotypes: phenotype A, with a larger buoyant LDL subfraction, and phenotype B, with smaller and denser LDL subfraction. These small, dense low-density lipoprotein cholesterol (sdLDL-C) particles have been recognized as more atherogenic due to their better penetration into the arterial wall, their lower binding affinity for the LDL receptor, their prolonged plasma half-life and lower resistance to oxidative stress compared to large buoyant LDL-C [5-8]. Some prospective studies have demonstrated an association between phenoltype B (sdLDL-C) and the risk of coronary heart disease (CHD) [9, 10]. Several observational studies investigated the relationship between SHypo, dyslipidaemia and the risk of CHD with heterogeneous results [11-19]. 
The aim of the present study was to evaluate the lipid profile in patients with subclinical hypothyroidism (SHypo) in comparison to controls and to determine the association of SHypo and dyslipidemia in an attempt to find importance of small dense low-density lipoprotein cholesterol (sdLDL-C) in the process of atherosclerosis.

\section{MATERIAL AND METHODS}

This study was conducted in General Hospital Zabok and Hospital of Croatian Veterans. The protocol of the study was approved by the Ethical Committee of General Hospital Zabok and Hospital of Croatian Veterans, (06.06.2014. No: 2567), and the Ethical Committee University of Zagreb, School of Medicine (23.10.2014. No: 380-5910106.14-55/223). Each participant gave a written informed consent to participate.

Volunteers, 36-newly diagnosed SHypo female patients aged 30-70 years and 64 aged matched euthyroid healthy female controls were included in the study according to the inclusion and exclusion criteria mentioned below. The history of the current illness, medication, menopausal period, pregnancy, family history (previous stroke or ischemic heart disease) and alcohol consumption and cigarette smoking were noted in a previously compiled form. Body weight and height were measured in kilograms $(\mathrm{kg})$ and meters $(\mathrm{m})$. The body mass index (BMI) was calculated as the body mass divided by the square of the body height, and is universally expressed in units of $\mathrm{kg} / \mathrm{m}^{2}$. BMI from 18.5 up to 24.99 indicated optimal weight, from 25 up to 30 indicated the person was overweight, and from 30 upwards suggested the person was obese. BMI lower than 18.5 suggested the person was underweight [20].

\section{DEFINITION OF SUBCLINICAL HYPOTHYROIDISM}

Diagnosis of SHypo was based on the finding of high TSH levels associated with normal free thyroxine (fT4) levels. Wiersinga subdivided SHypo into grade IA (TSH $>4.0$ to $10 \mathrm{mU} / \mathrm{L})$ and grade IB ( $\geq 10 \mathrm{mU} / \mathrm{L}$ ) [2]. Croatian Thyroid Society Guidelines for Rational Detection of Thyroid Dysfunction defined subclinical hypothyroidism if fT4 is normal with mildly elevated TSH (5-10 mU/lL) [21]. In this study we took the reference ranges from our laboratory that had previously been standardized as follows: TSH: $0.35-4.9 \mathrm{mlU} / \mathrm{L}$ and fT4:9-19 $\mathrm{pmol} / \mathrm{L}$, therefore for subclinical hypothyroidism we took $\mathrm{TSH}$ value range $4.9-10 \mathrm{mlU} / \mathrm{L}$.

\section{INCLUSION/EXCLUSION CRITERIA}

Inclusion criteria: 1) Female, 2.) Age: 30-70, 3) Newly diagnosed SHypo (TSH: 4.9-10 mlU/L, normal fT4: 9-19pmol/L), 4) Euthyroid subjects: (TSH: 0.35-4.9, fT4: 9-19 pmol/L).

Exclusion criteria: 1) Previously diagnosed thyroid disease (hypothyreosis, hyperthyreosis, thyroidectomy), 2) Diabetes mellitus, 3) Polycystic ovary syndrome, ovariectomy, 4) Renal and hepatic dysfunction, 5) Heart failure, 6) Stroke or ischemic heart disease, 7) Other systemic disease, 8) Primary or secondary dyslipidemia, 9) Cancer, 10) Subjects receiving drugs known to affect the thyroid or lipid metabolism (hypolipidemic drugs, oral contraceptives or hormone replacement therapy including thyroxine supplements, amiodarone, etc.), 11) Pregnancy.

The subjects were selected from the cases referred to our Biochemistry laboratory by other departments (Internal medicine, Gynecology, Neurology) requesting for thyroid profile, suspecting different thyroid disorders. Based on the results of thyroid profile, those patients with elevated serum TSH levels (between 4.9 and $10 \mathrm{mlU} / \mathrm{L}$ ) with normal fT4 levels (9-19 pmol/L) were diagnosed with subclinical hypothyroidism. Later in these patients fasting lipid profile and high-sensitivity C-reactive protein (hs-CRP) were estimated. Controls were age matched healthy euthyroid female subjects (Figure 1).

\section{LABORATORY PROCEDURES}

After 12 hours of overnight fasting, blood samples were collected from all participants for biochemical parameters measurement. Blood samples were centrifuged within 30 minutes at $3000 \mathrm{rpm}$ for $5 \mathrm{~min}$ and serum was separated. The sera were stored at $-20^{\circ} \mathrm{C}$, and for sdLDL-C at $-80^{\circ} \mathrm{C}$ until assayed.

Serum fT4 and TSH levels were estimated using Chemiluminescent Microparticle Immunoassay (CMIA) technology with commercial kits (ARCHITECT) on ARCHITECT i1000SR Immunoassay Analyzer. The normal range for TSH is 0.35 $4.9 \mathrm{mlU} / \mathrm{L}$, and for fT4 is $9-19 \mathrm{pmol} / \mathrm{L}$. Serum levels of total cholesterol (TC), triglyceride (TG), high-density lipoprotein (HDL) and low-density lipoprotein (LDL-C) were determined by enzymatic colorimetric assay with commercial kits (Beckman Coulter) on Beckman Coulter Analyzer (Recommended values for $\mathrm{TC}:<5.0 \mathrm{mmol} / \mathrm{L}, \mathrm{TG}<$ $1.7 \mathrm{mmol} / \mathrm{L}$, HDL-C $>1.2 \mathrm{mmol} / \mathrm{L}$, LDL-C < $3.0 \mathrm{mmol} / \mathrm{L}$ ). Serum levels of hs-CRP were measured by a latex-enhanced turbidimetric 
immunoassay method using hs-CRP Latex reagents (Beckman Coulter) on Beckman Coulter Analyzer. The normal range for hs-CRP is $0.0-5.0 \mathrm{mg} / \mathrm{L}$. Serum levels of sdLDL-C were measured using a sdLDL-EX "SEIKEN" test - spectrophotometric assay with commercial kits (Randox). Reference intervals for sdLDL for women - younger group $(21-54$ years $)=9.5-42.5 \mathrm{mg} / \mathrm{dL}=0.246-1.102 \mathrm{mmol} / \mathrm{L}$, older group (55-75 years) $10.7-48.7 \mathrm{mg} / \mathrm{dL}=$ $0.276-1.259 \mathrm{mmol} / \mathrm{L}$.

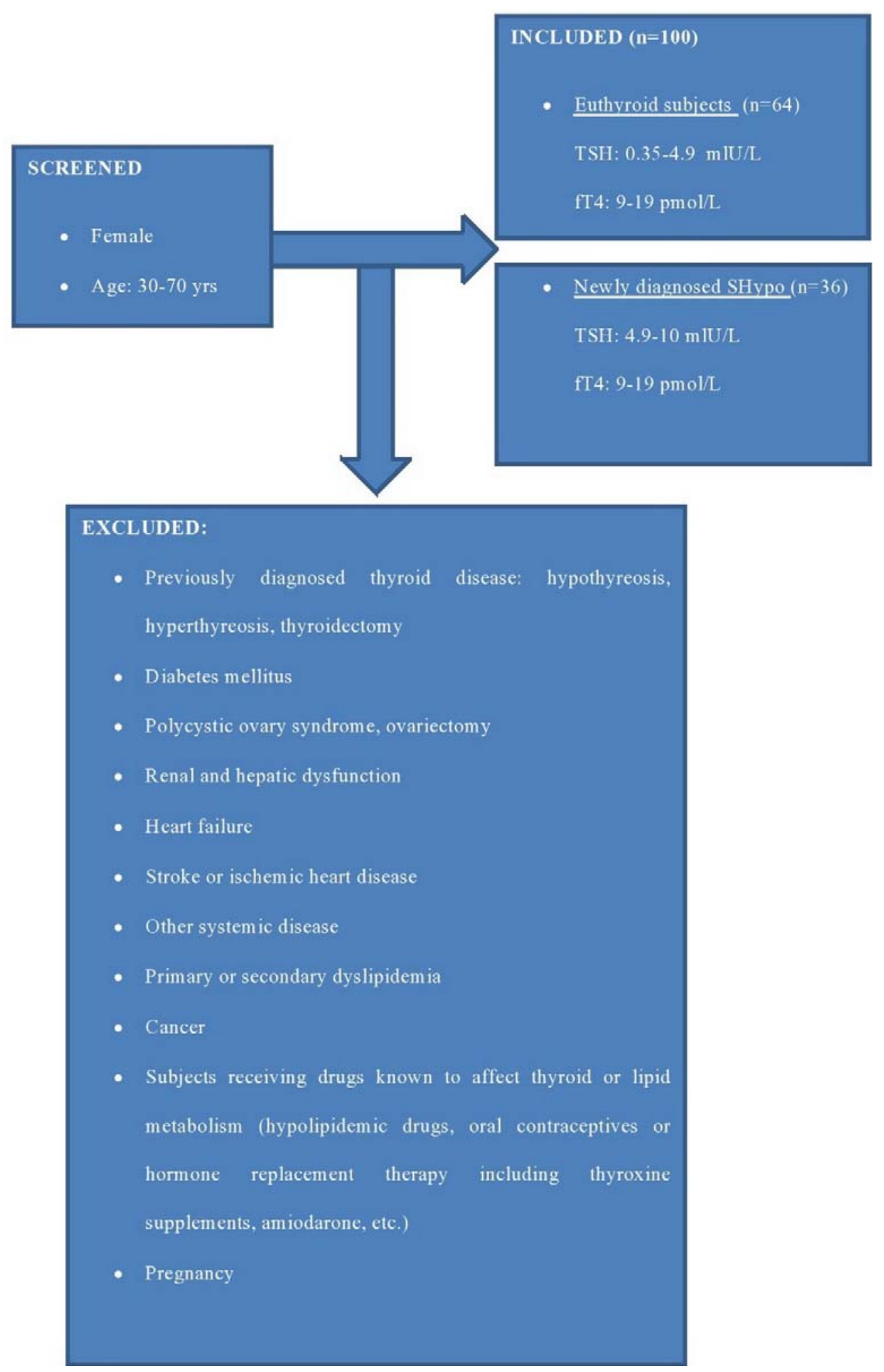

Figure 1. Flow chart. 


\section{STATISTICAL ANALYSIS}

Statistical analyses were performed using Statistica, version 10 (StatSoft Inc., Tulsa, OK, USA). Quantitative variables were tested for normality using the Kolmogorov-Smirnov test and described with appropriate descriptive statistics measures. Difference in distribution of age between two groups was analysed using Mann-Whitney U test for independent groups. Distributions of dichotomised parameters in two groups were presented as absolute frequencies and analysed using Pearson's $\chi^{2}$ test. Odds ratio was used as a measure of association between thyroid status and level of some lipid status parameters.

Required sample size for Pearson's $\chi^{2}$ test with one degree of freedom, effect size $=0.5$, power of test $=0.8$ at significance level 0.05 was 32 .

Results were interpreted at $5 \%$ significance level.

\section{RESULTS}

In this study 100 female subjects participated ranging from 30-70 years. The median age was 50 years. Central tendency and dispersion measures of quantitative variables are shown in Table 1. The median of TC was $5.6 \mathrm{mmol} / \mathrm{L}$, of TG was $1.2 \mathrm{mmol} / \mathrm{L}$ and of HDL was $1.5 \mathrm{mmol} / \mathrm{L}$. Median value of LDL-C was $3.5 \mathrm{mmol} / \mathrm{L}$ and of sdLDL-C $0.8 \mathrm{mmol} / \mathrm{L}$. Median value of TSH was $2.9 \mathrm{mlU} / \mathrm{L}$ and median of fT4 was $13 \mathrm{pmol} / \mathrm{L}$. Median of CRP was $1.3 \mathrm{mg} / \mathrm{L}$ and of BMI $25.9 \mathrm{mg} / \mathrm{L}$. Half of the subjects were in postmenopausal period, with median of the period 6 years ( $0-33$ years). 60 subjects were overweight or obese (Table 1).
Of the 100 subjects, 77 subjects had elevated value of total cholesterol $(>5 \mathrm{mmol} / \mathrm{L}), 17$ subjects had elevated value of triglycerides $(>1.7 \mathrm{mmol} / \mathrm{L})$, 16 subjects had reduced value of $\mathrm{HDL}<$ $1.2 \mathrm{mmol} / \mathrm{L}$ and 18 subjects had elevated value of sdLDL-C (Elevated value of sdLDL-C was defined for women - younger group (21-54 years) $>$ $1.099 \mathrm{mmol} / \mathrm{L}$, older group (55-75 years) > $1.259 \mathrm{mmol} / \mathrm{L}$ ) (Figure 2).

Of the 100 female subjects included in the study, 36 met the criteria for the group with subclinical hypothyroidism, whereas 64 met the criteria for the control group. 9 subjects had elevated hs-CRP. 5 subjects consumed alcoholic drink (more than one alcoholic beverage per week), and the 13 subjects were cigarette smokers. 42 subjects had positive family history of CHD (coronary heart disease: myocardial infarction or angina pectoris), or CVD (cerebrovascular disease: previous stroke or TIA). 36 subjects were previously diagnosed with hypertension and use antihypertensive drugs (Figure 2).

Distribution of subjects according to the lipid status parameters, CRP and BMI between SHypo and control group are shown in Table 2. Parameters were dichotomised into high or low, based on the criteria described in Material and methods paragraph.

Differences in distribution of subjects between SHypo and control group were confirmed for two parameters of lipid status, between SHypo and control group, higher sdLDL-C and TG $>1.7$. Elevated levels of sdLDL-C and triglycerides are more common in SHypo group than in control (euthyroid) group. On the other hand, for other parameters TC, HDL, LDL as well as for CRP, and BMI no significant differences were observed.

Table 1

Central tendency and dispersion measures of quantitative variables

\begin{tabular}{lccc}
\hline & Mean \pm SD & Median & min-max \\
\hline TSH $(\mathrm{mlU} / \mathrm{L})$ & $3.5 \pm 2.3$ & 2.9 & $0.4-10$ \\
\hline fT4 $(\mathrm{pmol} / \mathrm{L})$ & $12.9 \pm 1.3$ & 13 & $10.5-16$ \\
\hline TC $(\mathrm{mmol} / \mathrm{L})$ & $5.8 \pm 1.1$ & 5.6 & $3.5-9.2$ \\
\hline HDL $(\mathrm{mmol} / \mathrm{L})$ & $1.5 \pm 0.3$ & 1.5 & $1-2.5$ \\
\hline LDL $(\mathrm{mmol} / \mathrm{L})$ & $3.6 \pm 0.9$ & 3.5 & $1.7-6.3$ \\
\hline sdLDL- C $(\mathrm{mmol} / \mathrm{L})$ & $0.8 \pm 0.4$ & 0.8 & $0.3-2.7$ \\
\hline TG $(\mathrm{mmol} / \mathrm{L})$ & $1.3 \pm 0.6$ & 1.2 & $0.4-3.5$ \\
\hline hs-CRP $(\mathrm{mg} / \mathrm{L})$ & $2.2 \pm 2.6$ & 1.3 & $0.2-22$ \\
\hline BMI & $25.9 \pm 4.2$ & 25.9 & $17.9-36.7$ \\
\hline
\end{tabular}

Note: $\mathrm{TSH}=$ Thyroid- stimulation hormone, $\mathrm{fT} 4=$ Free thyroxine, $\mathrm{TC}=$ Total cholesterol, HDL = High density lipoprotein, LDL = Low density lipoprotein, sdLDL-C $=$ small dense low density lipoprotein cholesterol, $\mathrm{TG}=$ Triglyceride, hs-CRP $=$ high sensitivity $\mathrm{C}$ - reactive protein, BMI: Body mass index. 


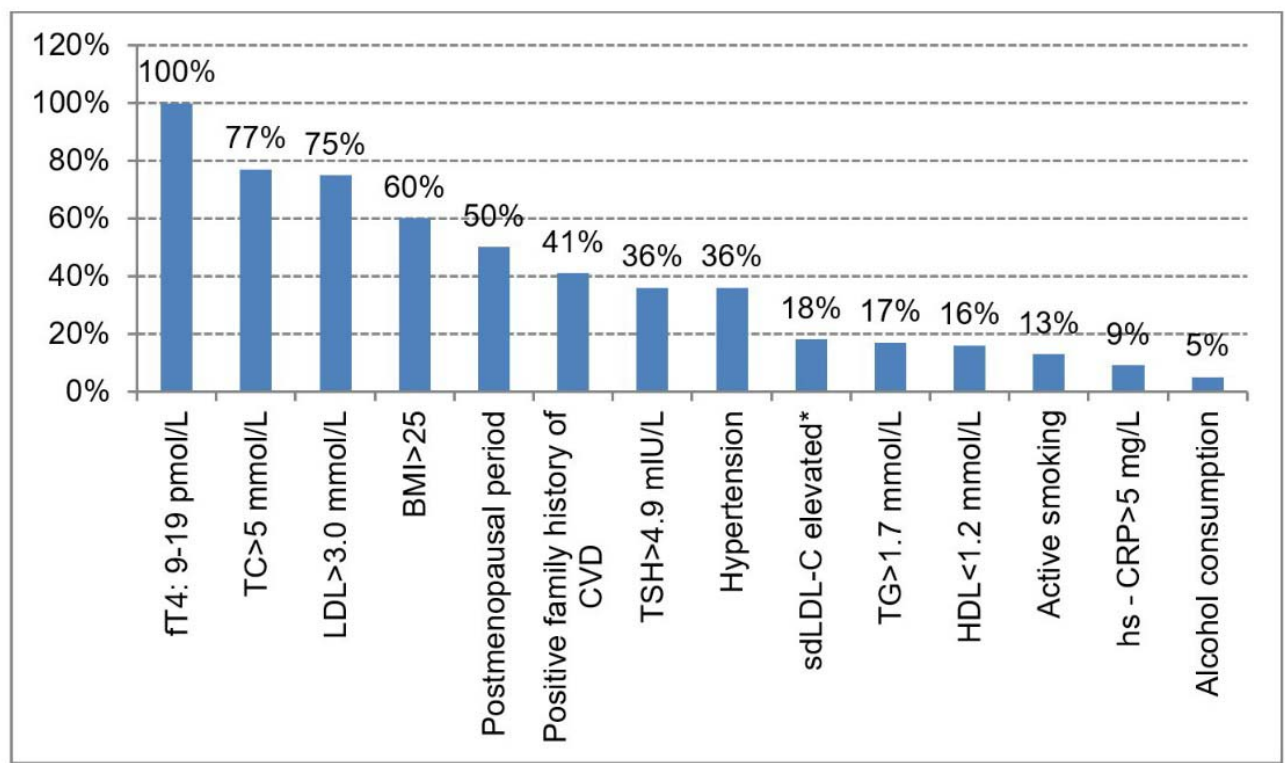

Figure 2. Percentage of subjects with corresponding values of qualitative variables, $\% \mathrm{n}=100$.

Note: $\mathrm{TC}=$ Total cholesterol, $\mathrm{TG}=$ Triglyceride, $\mathrm{HDL}=$ High density lipoprotein, $\mathrm{LDL}=\mathrm{Low}$ density lipoprotein, sdLDL $=$ small dense LDL: Elevated: $>1.099 \mathrm{mmol} / \mathrm{L}(21-54 \mathrm{yrs}) ;>1.259 \mathrm{mmol} / \mathrm{L}$ (55-75yrs), TSH $=$ Thyroid-stimulation hormone, fT4 $=$ Free thyroxine, hs-CRP $=$ high-sensitivity $\mathrm{C}$-reactive protein, $\mathrm{CVD}=$ cerebrovascular disease, $\mathrm{BMI}=$ Body mass index.

Table 2

Differences in lipid status parameters, hs-CRP and BMI between SHypo and control group

\begin{tabular}{lccccc}
\hline & $\begin{array}{c}\text { SHypo } \\
\mathrm{N}=36\end{array}$ & $\begin{array}{c}\text { CONTROL } \\
\mathrm{N}=64\end{array}$ & $\begin{array}{c}\text { Pearson's } \chi^{2} \text { test value } \\
(\mathrm{DF}=1)\end{array}$ & $\begin{array}{c}\text { P value } \\
(\mathrm{CI} 95 \%)\end{array}$ \\
\hline $\mathrm{TC}>5(\mathrm{mmol} / \mathrm{L})$ & 30 & 47 & 1.27 & 0.259 & 0.892 \\
\hline $\mathrm{HDL}<1,2(\mathrm{mmol} / \mathrm{L})$ & 6 & 10 & 0.02 & 0.149 & \\
\hline $\mathrm{LDL}>3(\mathrm{mmol} / \mathrm{L})$ & 30 & 45 & 6.1 & 0.014 & 3.6 \\
\hline $\begin{array}{l}\text { sdLDL-C } \\
\text { elevated }(\mathrm{mmol} / \mathrm{L})\end{array}$ & 11 & 7 & 6.14 & 3.1 \\
\hline $\mathrm{TG}>1.7(\mathrm{mmol} / \mathrm{L})$ & 10 & 7 & $4.63)$ & $(1.1-9.1)$ \\
\hline $\mathrm{hs}-\mathrm{CRP}>5(\mathrm{mg} / \mathrm{L})$ & 4 & 5 & 0.31 & 0.031 & 0.58 \\
\hline BMI $>25$ & 25 & 35 & 2.1 & 0.148 & \\
\hline
\end{tabular}

Note: SHypo $=$ Subclinical hypothyroidism group $(\mathrm{TSH}>4.9 \mathrm{mlU} / \mathrm{L}), \mathrm{CONTROL}=$ Control group $(\mathrm{TSH}<4.9 \mathrm{mlU} / \mathrm{L}), \mathrm{DF}=$ degrees of freedom, $\mathrm{P}$ value for Pearson's $\chi 2$ test, TC $=$ Total cholesterol, HDL $=$ High density lipoprotein, LDL $=$ Low density lipoprotein, sdLDL-C = small dense low density lipoprotein cholesterol: Elevated": > 1.099 mmol/L (21-54 yrs); > 1,259 mmol/L (55-75yrs), $\mathrm{TG}=$ Triglyceride, hs-CRP $=$ high sensitivity $\mathrm{C}$-reactive protein, BMI: Body mass index.

\section{DISCUSSION}

In the current study, we investigated the relationship between subclinical hypothyroidism and dyslipidemia in comparison with plasma levels of TSH, fT4, TC, TG, HDL, LDL, hs-CRP and sdLDL-C using a newly automated homogeneous sdLDL-C assay. Our data showed differences in lipid status between SHypo and control group. Subjects with SHypo had significantly higher level of sdLDL-C and TG compared with control (euthyroid) group. On the other hand, for other parameters TC, HDL, LDL, hs-CRP, and BMI no significant differences were observed between these two groups.

Luboshitzky et al. also supported the findings of our study. They have concluded that SHypo in middle-aged women is associated with hypertension, hypertriglyceridemia and elevated TC/HDL-C ratio [22]. Another study has indicated that SHypodyslipidemia may also be accompanied by increased TG levels [23]. Tourner et al. have reported that the TG concentrations of SHypo patients are higher than of control subjects [24]. 
It is known that SHypo is associated with some functional cardiac abnormalities, such as left ventricular diastolic dysfunction, vascular abnormalities - increased vascular resistance, arterial stiffness, endothelial dysfunction and atherosclerosis [25]. Based on these findings hypothyroid patients tend to have higher CHD risk. Some studies investigated connection between SHypo and dyslipidemia with heterogeneous results. In a crosssectional study of 1149 women aged $\geq 55$ years and in large studies subjects with subclinical hypothyroidism had a significantly higher prevalence of CHD than in euthyroid subjects [14, 26]. The initial analysis of the Whickham Survey found no association between autoimmune thyroid disease and SHypo over 20 years of follow-up, but re-analysis of the data, looking specifically at individuals with SHypo found an increase in CHD events and mortality [27]. On the other hand, a survey of 3233 older individuals did not show a significant difference in the prevalence of CHD, stroke, or peripheral artery disease between SHypo and euthyroid subjects $[25,28]$. In the EPIC-Norfolk prospective study significantly increased concentrations of TC, LDL-C and TG were found in SHypo women, but despite the association between thyroid hormone levels and cardiovascular risk factors, thyroid status was not statistically significantly associated with the risk of future CHD or all-cause mortality in this large cohort [19].

In hypothyroidism, lipoprotein lipase activity in the adipose tissue has been found normal or decreased, which results in the decrease of hepatic lipase activity and clearance of triglyceride-rich lipoproteins and leads to normal or increased levels of TG $[3,4,29,30]$.

Atherogenic dyslipidemia is one of the most important factors of association of subclinical hypothyroidism and CHD [25]. LDL-C plays an important role in development of atherosclerosis, but it has been shown that some patients with a history of CHD had normal LDL which highlights the importance of determination of its qualitative composition.

There are a limited number of reports which investigated the relationships between subclinical hypothyroidism and sdLDL-C. In most previous studies LDL subclass measurements are based on different principles: gradient gel electrophoresis, nuclear magnetic resonance (NMR), spectroscopy and analytical ultracentrifugation. All of these methods required specialized skills and equipment, and thus are not suitable for use in general clinical practice. In this study we used a direct, homogeneous method for the quantification of sdLDL-C, a modified photometric test procedure which is commercially available, fully applicable to an automated chemistry analyzer without manual pretreatment of the sample, reducing the assay time to $10 \mathrm{~min}$, and suitable for use in general clinical practice [5].

Results of Abbas et al.'s study supported an independent association between LDL particle size phenotype, plasma TG and thyroid status [26]. In another study that investigated overt hypothyroid patients, no significant discordance in percentages of B phenotype (predominance of sdLDL-C) compared to the controls was found [30]. These conflicting reports in the literature may be a result of differences in sex and age of participating patients, differences in populations studied, the degree and duration of subclinical hypothyroidism, different definition of subclinical hypothyroidism, depending which was under the limit values for $\mathrm{TSH}$, as well as differences in study design.

\section{CONCLUSION}

Our data showed that the SHypo is associated with some lipid abnormalities, including higher levels of serum TG and sdLDL-C. Namely, sdLDL-C is a strong and independent predictor of risk of CVD. Therefore, based on these results it can be concluded that careful screening of patients with SHypo, which is necessary to determine the lipid status, including the determination of qualitative characteristics of LDL particle, i.e., serum sdLDL-C, with the aim of timely treatment of SHypo and dyslipidemia and prevention of the development of atherosclerosis and potential complications such as cardiovascular and cerebrovascular diseases.

However, further studies are needed with larger population size and a "follow-up" period to monitor subjects and include those taking substitution hormone therapy (if therapy was introduced).

\footnotetext{
Acknowledgment. We would like to thank all the study subjects, including patients and the technical staff for their participation and co-operation in the study.
}

Conflict of interest. The authors declare that there are not conflicts of interest. 
Introducere. Hipotiroidismul cât şi hipertiroidismul se asociază cu comorbidități cardiovasculare şi neurologice. Legătura hipotiroidismului subclinic cu aceste comorbidități este încă controversată în literatură. Scopul studiului a fost de a evalua profilul lipidic la paciente cu hipotiroidism subclinic (sHypo) comparat cu martori eutiroidieni şi de a evalua particulele de colesterol sdLDLC-C (small dense low-density lipoprotein) la aceşti pacienți precum şi asocierea acestora cu ateroscleroza.

Materiale şi metode. Au fost recrutate 100 de paciente cu vârste cuprinse intre 30 şi 70 de ani- 64 de paciente eutiroidiene şi 36 paciente sHypo. Le-au fost analizate nivelurile hs-CRP, profilul lipidic (inclusiv nivleurile sdLDL-C). Le-au fost luate date de anamneză şi date antropometrice şi le-a fost calculat BMI.

Rezultate. Au fost observate modificări ale profilului lipidic la pacientele cu sHypo, cu niveluri mai mari ale trigliceridelor şi ale sd-LDL-C comparativ cu pacientele eutiroidiene.

Concluzii. Este important să se evalueze nivelurile sd-LDL-C la pacientele cu hipotiroidism sublcinic cât mai precoce întrucât acestea se asociază cu comorbidități cardiovasculare şi cerebrale. Nivelurile sd-LDL-C sunt buni indicatori ai riscului cardiovascular.

Correspondence to: MAIDA SEFEROVIC SARIC,

General Hospital Zabok and Hospital of Croatian Veterans,

Bracak 8, 49210 Zabok, Croatia

Phone: +385-49-204-390, Mob: +385-98-540-285

E-mail: maja.seferovic@zg.t-com.hr

\section{REFERENCES}

1. FATOURECHI V. Subclinical hypothyroidism: an update for primary care physicians. Mayo Clin Proc. 2009; 84(1):65-71.

2. WIERSINGA WM. Guidance in subclinical hyperthyroidism and subclinical hypothyroidism: are we making progress? Eur Thyroid J. 2015; 4(3):143-8.

3. MALEKI N., KAZEROUNI F., HEDAYATI M., RAHIMIPOUR A., PARHAM M. Subclinical hypothyroidism and the alterations of lipid profile as a cardiovascular risk factor. J Paramed Sci. 2015; 6(4):2008-4978.

4. RIZOS CV., ELISAF MS., LIBEROPOULUS EN. Effects of thyroid dysfunction on lipid profile, Open Cardiovasc Med J. 2011; 5:76-84.

5. VANDERMEERSCH A., AMEYE S., PUYPE D., PETITJEAN D., De BUYZERE M., LANGLOIS MR. Estimation of the lowdensity lipoprotein (LDL) subclass phenotype using a direct, automated assay of small dense LDL-cholesterol without sample pretreatment. Clin Chim Acta. 2010; 411(17-18):1361-66.

6. NATIONAL CHOLESTEROL EDUCATION PROGRAM (NCEP) EXPERT PANEL ON DETECTION, EVALUATION, AND TREATMENT OF HIGH BLOOD CHOLESTEROL IN ADULTS (Adult Treatment Panel III), Third report of the National cholesterol education program (NCEP) expert panel on detection, evaluation, and treatment of high blood cholesterol in adults (Adult treatment panel III) final report. Circulation. 2002; 106(25):3143-3421.

7. AUSTIN MA., BRESLOW JL., HENNEKENS CH., BURING JE., WILLETT WC., KRAUSS RM. Low-density lipoprotein subclass patterns and risk of myocardial infarction. JAMA. 1988; 260(13):1917-21.

8. CARMENA R., DURIEZ P., FRUCHART JC. Atherogenic lipoprotein particles in atherosclerosis. Circulation. $2004 ; 109$ (23 Suppl 1):III2-7.

9. BERNEIS KK., KRAUSSS RM. Metabolic origins and clinical significance of LDL heterogeneity. J Lipid Res. 2002; 43(9):1363-79.

10. LAMARCHE B., TCHERNOF A., MOORJANI S., CANTIN B., DAGENAIS GR., LUPIEN PJ., et al. Small, dense LDL particles as a predictor of the risk of ischemic heart disease in men. Prospective results from the Quebec Cardiovascular Study. Circulation. 1997; 95(1):69-75.

11. VERHOYE E., LANGLOIS MR., ASKLEPIOS INVESTIGATORS. Circulating oxidized low-density lipoprotein: a biomarker of atherosclerosis and cardiovascular risk? Clin Chem Lab Med. 2009; 47(2):128-37.

12. TOGNINI S., POLINI A., PASAQUALETTI G., URSINO S., CARACCIO N., ERDEGHINI M., et al. Age and gender substantially influence the relationship between thyroid status and the lipoprotein profile: results from a large cross-sectional study. Thyroid. 2012; 22(11):1096-103.

13. HAK AE., POLS HA., VISSER TJ., DREXHAGE HA., HOFMAN A., WITTEMAN JC. Subclinical hypothyroidism is an independent risk factor for atherosclerosis and myocardial infarction in elderly women: the Rotterdam Study. Ann Intern Med. 2000; 132(4):270-8. 
14. WALSH JP., BREMNER AP., BULSARA MK., O'LEARY P., LEEDMAN PJ., FEDDEMA P., et al. Subclinical thyroid dysfunction as a risk factor for cardiovascular disease. Arch Intern Med. 2005; 165(21):2467-72.

15. COOPER DS. Clinical practice. Subclinical hypothyroidism. N Engl J Med. 2001; 345(4):260-5.

16. KLEIN I. Subclinical hypothyroidism - just a high serum thyrotropin concentration or something else? J Clin Endocrinol Metab. 2013; 98(2):508-10.

17. DUNTAS LH., BRENTA G. The effect of thyroid disorders on lipid levels and metabolism. Med Clin North Am. 2012; 96(2):269-81.

18. PEARCE EN. Update in lipid alterations in subclinical hypothyroidism. J Clin Endocrinol Metab. 2012; 97(2):326-33.

19. BOEKHOLDT SM., TITAN SM., WIERSINGA WM., CHATTERJEE K., BASART DC., LUBEN R., et al. Initial thyroid status and cardiovascular risk factors: the EPIC-Norfolk prospective population study. Clin Endocrinol (Oxf). 2010; 72(3):40410.

20. WORLD HEALTH ORGANIZATION. “BMI Classification”. Global Database on Body Mass Index. 2006.

21. KUSIC Z., JUKIC T., FRANCESCHI M., DEBELIC N., RONCEVIC S., LUKINAC L. Croatian Thyroid Society guidelines for rational detection of thyroid dysfunction. Lijec Vjesn. 2009; 131(11-12):328-38.

22. LUBOSHITZKY R., AVIV A., HERER P., LAVIE L. Risk factors for cardiovascular disease in women with subclinical hypothyroidism. Thyroid. 2002; 12(5):421-5.

23. KARTHICK N., DILLARA K., POORNIMA KN., SBHASINI AS. Dyslipidaemic changes in women with subclinical hypothyroidism. J Clin Diagn Res. 2013; 7(10):2122-5.

24. TOURNER F., ALTINOVA AE., KARAKOC A., YETKIN I., AYVAZ G., CAKIR N., et al. Risk factors for cardiovascular disease in patients with subclinical hypothyroidism. Adv Ther. 2008; 25(5):430-7.

25. PEARCE SH., BRABANT G., DUNTAS LH., MONZANI F., PEETERS RP., RAZVI S., et al. 2013 ETA Guideline: management of subclinical hypothyroidism. Eur Thyroid J. 2013; 2(4):215-28.

26. ABBAS JM., CHAKRABORTY J., AKANJI AO., DOI SA. Hypothyroidism results in small dense LDL independent of IRS traits and hypertriglyceridemia. Endocr J. 2008; 55(2):381-9.

27. RAZVI S., WEAVER JU., VANDERPUMP MP, PEARCE SH. The incidence of ischemic heart disease and mortality in people with subclinical hypothyroidism: re-analysis of the Whickham Survey cohort. J Clin Endocrinol Metab 2010; 95:1734-40.

28. CAPPOLA AR., FRIED LP., ARNOLD AM., DANESE MD., KULLER LH., BURKE GL., et al. Thyroid status, cardiovascular risk, and mortality in older adults. JAMA 2006; 295(9):1033-41.

29. LAM KS., CHAN MK., YEUNG RT. High-density lipoprotein cholesterol, hepatic lipase and lipoprotein lipase activities in thyroid dysfunction-effects of treatment. Q J Med. 1986; 59(229):513-521.

30. PEARCE EN., WILSON PW., YANG Q., VASAN RS., BRAVERMAN LE. Thyroid function and lipid subparticle sizes in patients with short-term hypothyroidism and a population-based cohort. J Clin Endocrinol Metab. 2008; 93(3):888-94.

Received February 4, 2017 